\title{
Arahan Pengembangan Pariwisata dalam rangka Mengurangi Ketidakmerataan Pariwisata Studi Kasus Kabupaten Badung dan Gianyar
}

\author{
Laksmita Dwi Hersaputri dan Eko Budi Santoso \\ Departemen Perencanaan Wilayah dan Kota, Fakultas Teknik Sipil dan Perencanaan, Institut \\ Teknologi Sepuluh Nopember (ITS) \\ e-mail: eko_budi@urplan.its.ac.id
}

\begin{abstract}
Abstrak-Pariwisata merupakan sektor andalan pada perekonomian Provinsi Bali. Pariwisata Bali sebagian besar berpusat pada Kabupaten Badung dan Denpasar. Padahal Kabupaten Gianyar memiliki jumlah potensi wisata yang lebih besar namun pendapatan daerah dari sektor wisata jauh lebih kecil dibandingkan dengan Kabupaten Badung. Ketidakmerataan pariwisata di Kabupaten Badung dan Gianyar dapat dilihat dari beberapa aspek seperti pada aspek fasilitas, akomodsi, keberagaman atraksi wisata yang dapat dilakukan, serta keberadaan pengelola daya tarik wisata. Berdasarkan permasalahan tersebut maka penelitian ini bertujuan untuk merumuskan arahan pengembangan pariwisata di Kabupaten Badung dan Gianyar untuk mengatasi ketidakmerataan perkembangan pariwisata dan pemerataan pendapatan daerah. Metode analisis yang digunakan dalam merumuskan arahan pengembangan adalah deskriptif komparatif. Dari hasil analisis terdapat beberapa arahan pengembangan pada masing-masing kabupaten. Arahan pengembangan pada Kabupaten Gianyar difokuskan pada penambahan jenis araksi/kegiatan wisata, meningkatkan jumlah akomodasi, restoran, dan fasilitas pendukung wisata, kerjasama dalam pengelolaan DTW, serta meningkatan rute Bus Sarbagita di Kabupaten Gianyar. Sedangkan arahan pengembangan untuk Kabupaten Badung adalah peningkatan jumlah akomodasi di Badung bagian utara, serta kerjasama antara pemerintah, swasta, dan masyarakat dalam mengelola daya tarik wisata.
\end{abstract}

Kata Kunci-Arahan, Ketidakmerataan, Pariwisata.

\section{PENDAHULUAN}

$\mathrm{P}$ ARIWISATA merupakan salah satu sektor potensial dalam pengembangan serta pembangunan suatu kawasan. [1] Sektor pariwisata memberikan share terbesar pada PDRB Provinsi Bali. [2] Bali selatan yang terdiri dari Kabupaten Badung, Denpasar, Gianyar, dan Tabanan merupakan salah satu pusat pariwisata di Provinsi Bali. Secara keseluruhan Bali selatan memiliki jumlah potensi wisata sebanyak 146 daya tarik wisata dengan persebaran 36 daya tarik wisata di Kabupten Badung, 28 daya tarik di Kota Denpasar, 59 daya tarik di Kabupaten Gianyar, dan 23 daya tarik di Kabupaten Tabanan. [3]

Pengembangan pariwisata di Provinsi Bali belum merata pada semua kabupaten, pengembangan pariwisata hanya berpusat di Kabupaten Badung dan Denpasar. Hal tersebut menyebabkan perekonomian wilayah tersebut lebih tinggi dibandingan dengan wilayah lainnya.[4] Pada Tahun 2015 persentase PDRB sektor akomodasi makan dan minum di Kabuapten Badung dan Denpasar lebih besar dibandingakan dengan Kabupaten Gianyar dan Tabanan yaitu $26.18 \%$ dan $23.09 \%$. Sedangkan Kabupaten Gianyar dan Tabanan memiliki persentase sebesar $20.48 \%$ dan $18.27 \%$. [2]

Selain itu dari aspek ketersediaan fasilitas akomodasi makan dan minum, Kabupaten Badung dan Denpasar memiliki jumlah hotel dan restoran lebih banyak dibandingkan Kabupaten Gianyar dan Tabanan. Pada Tahun 2015 Kabupaten Badung memiliki jumlah hotel berbintang sebanyak 357 dan 491 hotel non bintang, Kota Denpasar memiliki 65 buah hotel berbintang dan 251 hotel non bintang, sedangkan Kabupaten Gianyar memiliki hotel berbintang sebanyak 49 dan 358 hotel non bintang, serta Kabupaten Tabanan memiliki 6 buah hotel berbintang dan 109 hotel non bintang. Begitu pula pada fasilitas untuk memenuhi kebutuhan wisatawan seperti restoran, pada Tahun 2015 Kabupaten Badung dan Denpasar memiliki jumlah restoran masing-masing 825 dan 449 buah, sedangkan Kabupaten Gianyar dan Tabanan memiliki jumlah restoran masing-masing 504 buah dan 32 buah.[2]

Dalam penelitian, lingkup wilayah difokuskan pada Kabupaten Badung dan Gianyar, dengan alasan karena Kabupaten Badung merupakan wilayah dengan pariwisata yang paling berkembang, dan Kabupaten Gianyar memiliki potensi yang paling besar namun belum berkembang dengan maksimal.

Salah satu tantangan pengembangan pariwisata adalah kondisi pengembangan pariwisata yang masih bertumpu pada daerah tujuan wisata utama tertentu saja. Hal tersebut menyebabkan terlampaunya daya dukung daerah tersebut, dan daerah lain yang memiliki potensi wisata tidak dapat mengembangkan potensi yang dimiliki sebagaimana mestinya.[5]

Berdasarkan permasalahan diatas sehingga dibutuhkan penelitian mengenai arahan pengembangan pariwisata untuk mengatasi ketidakmerataan pariwisata di Kabupaten Badung dan Gianyar.

\section{METODE PENELITIAN}

\section{A. Jenis dan Pendekatan Penelitian}

Jenis penelitian dalam penelitian ini adalah deskriftif 
kualitatif. pendekatan penelitian yang digunakan adalah pendekatan rasionalistik.[6]

\section{B. Variabel Penelitian}

Variabel penelitian dalam menentukan arahan pengembangan adalah atraksi atau kegiatan wisata yang dapat dilakukan, pemadangan yang dapat dinikmati, sesuatu yang dapat dibeli dilokasi wisata, keberadaan hotel berbintang, hotel melati, pendok wisata, restoran atau rumah mkan, fasilitas pendukung pariwisata, keberadaan lembaga pengelola daya tarik wisata, jarak daya tarik wisata dari bandara, dan jarak antar objek wisata.[7]

C. Metode Analisis : Merumuskan arahan pengembangan pariwisata untuk mengatasi ketidakmerataan pariwisata di Kabupaten Badung dan Gianyar

Metode analisis yang digunakan dalam menentukan arahan adalah analisis deskriptif komparatif. Input dalam analisis ini adalah potesi dan permasalahan dari masing-masing variabel penelitian kemudian dikomparasikan dengan best practice.

\section{HASIL DAN DISKUSI}

A. Merumuskan arahan pengembangan pariwisata untuk mengatasi ketidakmerataan pariwisata di Kabupaten Badung dan Gianyar

Permususan arahan dilakukan dengan anlisis deskriptif dengan mengkomparasikan karakteristik dari masing-masing variabel penelitian dengan best pactice. Berikut merupakan arahan pengembangan berdasarkan masing-masing variabel: 1. Atraksi atau Kegiatan wisata yang dapat dilakukan

Tabel 1.

Arahan pengembangan variabel atraksi wisata

\begin{tabular}{lll}
\hline \hline \multicolumn{2}{c}{ Potensi masalah } & \multicolumn{2}{c}{ Best practice } \\
\hline Terdapat tradisi & siyat & Tradisi Mekotekan Kabupaten \\
sampiyan pada Pura & Badung; merupakan ritual rutin yang \\
Samuhan Tiga & dilakukan setiap 210 hari sekali, \\
& & sehari setelah hari raya kuningan. \\
& Tradisi tersebut mampu menarik \\
& minat wisatawan untuk berkunjung \\
& dan menyaksikan tradisi tersebut
\end{tabular}

Arahan Pengembangan :

Pelestarian tradisi leluhur Siyat Sampyan serta mempromosikan kegiatan tersebut sehingga menjadi salah satu daya tarik wisata budaya di Kabupaten Gianyar

\begin{tabular}{lrl}
\hline Wisata pantai di & Festival Bahari Kabupaten Badung; \\
Kabupaten Gianyar & merupakan festival yang melibatkan \\
belum berkembang & beberapa objek wisata pantai dengan \\
secara maksimal seperti & atraksi yang ditawarkan sesuai \\
pada Pantai Lebih, & dengan potensi yang dimiliki \\
Pantai Selukat, dan & masing-masing pantai tersebut.
\end{tabular}
pantai lainnya

\section{Arahan Pengembangan:}

Pengembangan kegiatan wisata pantai dalam bentuk even atau festival yang melibatkan beberapa objek wisat dengan atraksi wisata sesuai dengan potensinya masing-masing

Belum terdapat kegiatan Wisata pantai di Kabupaten Badung; unggulan yang menjadi pantai di Badung telah memiliki ciri ciri khas dari masing- khas seperti Pantai Tanjung Benoa masing objek wisata dengan kegiatan wisata tirta, Pantai pantai di Kabupaten Kedonganan dengan ciri khas

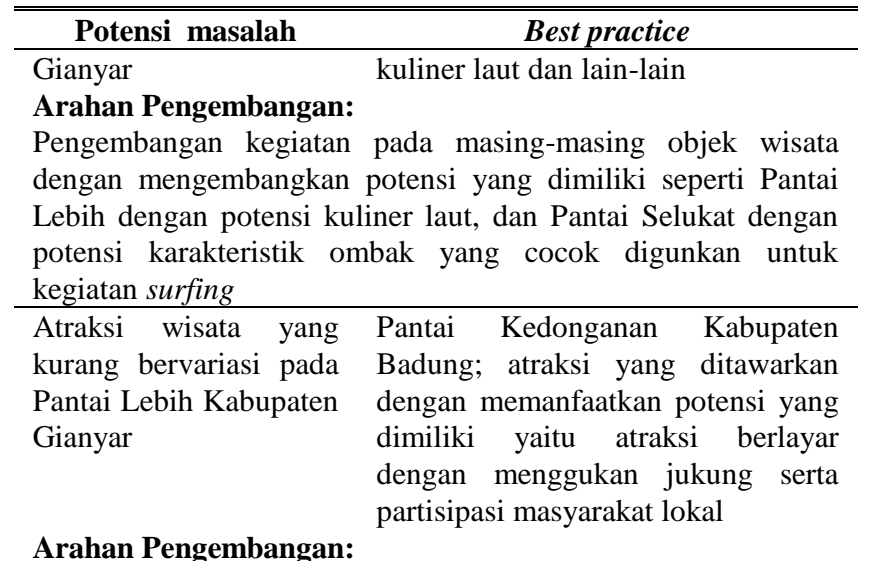

Pengembangan wisata layar di Pantai Lebih dengan melibatkan peran serta masyarakat

Sumber: Hasil analisis, 2017

2. Pemandangan yang dapat dinikmati

Tabel 2.

Arahan pengembangan variabel pemandangan yang dapat dinikmati

\begin{tabular}{lrl}
\hline \multicolumn{2}{c}{ Potensi masalah } & \multicolumn{2}{c}{ Best practice } \\
\hline Memiliki & potensi & Pantai Sanur, Kota Denpasar; \\
pemandangan & sunrise & Pantai Sanur menawarkan daya tarik \\
pada semua pantai di & berupa suasana sunrise dan telah \\
Kabupaten & Gianyar, & mampu menarik wisatawan untuk \\
namun & menarik & berkunjung untuk menyaksikan \\
wisatawan untuk & sunrise dan melaukan aktivitas \\
berwisata & & wisata lain
\end{tabular}

\section{Arahan Pengembangan:}

1. Penentuan lokasi strategis untuk menikmati sunrise pada Pantai Saba, Siyut, Selukat, dan Air Jeruk

2. Promosi atau branding wisata Pantai Saba, Siyut, Selukat, dan Air Jeruk sebagai pantai matahari terbit di Kabupaten Gianyar

3. Mengembangkan atraksi wisata lain untuk menarik minat wisatawan seeprti jogging dan bersepeda yang diikuti dengan penyediaan infrastruktur serta fasilitas lain yang dibutuhkan

Sumber: Hasil analisis, 2017

\section{Hotel Melati}

Tabel 3.

Arahan pengembangan variabel hotel melati

\begin{tabular}{llll}
\hline \hline \multicolumn{2}{c}{ Potensi masalah } & \multicolumn{3}{c}{ Best practice } \\
\hline Pada & Kabupaten & Kecamatan Kuta, Kuta Utara, Kuta \\
Gianyar hotel melati & Selatan; Keberadaan Hotel melati \\
sebagai besar hanya & yang tersebar di kecamatan tersebut \\
terletak & pada & mampu memenuhi & kebutuhan \\
Kecamatan Ubud dan & wisatawan yang & berkunjung \\
belum terdapat hotel & sehingga dapat meningkatkan \\
melati pada Kecamatan & perekonomian wilayah tersebut \\
Petang Kabupaten & & \\
Badung & & \\
Arahan Pengembangan: & \\
Penentuan lokasi strategis untuk lokasi hotel melati di \\
Kecamatan Tegalalang, Payangan Kabupaten Gianyar dan \\
Kecamatan Petang Kabupaten Badung \\
\hline \hline Sumber: Hasil analisis, 2017
\end{tabular}

4. Pondok Wisata

Tabel 4.

Arahan pengembangan variabel pondok wisata Potensi masalah 


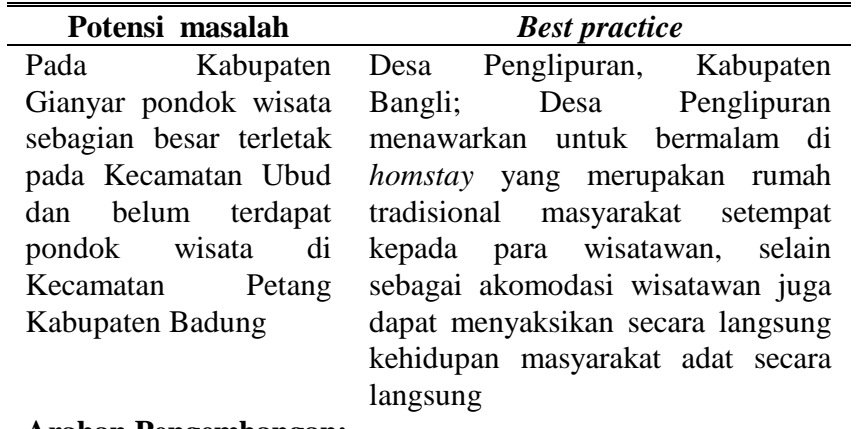

Arahan Pengembangan:

Mempersiapkan rumah masyarakat di Desa Wisata Batubulan, Celuk, Batuan, Bona di Kabupaten Gianyar dan Desa Wisata Baha Kabupaten Badung sebagai homestay bagi wisatawan yang ingin menginap serta mengetahui kehidupan masyarakat setempat

Sumber: Hasil analisis, 2017

\section{Restoran}

Tabel 5.

Arahan pengembangan variabel restoran

\begin{tabular}{ll}
\hline \hline \multicolumn{3}{c}{ Potensi masalah } & \multicolumn{3}{c}{ Best practice } \\
\hline Telah terdapat rumah & Kebupaten Badung sebgin \\
makan atau restorran masih & besar rumah makan dan \\
berpusat pada Kecamatan & restoran tedapat di setiap \\
Ubud, dan belum banyak kecamatan yang memiliki daya \\
tersedia di Kecamatan tarik wisata sehingga mampu \\
Sukawati, Tegalalang, memenuhi kebutuhan \\
Payangan, dan Blahbatuh \\
Arahan Pengembangan: \\
1.Penyediaan fasilitas berupa rumah makan dan restoran pada \\
Kecamatan Sukawati, Blahbatuh, Tegalalang, dan \\
Payangan Kabupaten Gianyar untuk memenuhi kebutuhan \\
wisatawan berwisata \\
2.Penyediaan rumah makan di Desa Bona, Batuan, Celuk, \\
Batubulan Kabupaten Gianyar dan Desa wisata Baha \\
Kabupaten Badung oleh masyarakat setempat \\
\hline \hline
\end{tabular}

Sumber: Hasil analsisi, 2017

6. Fasilitas Pendukung Wisata

Tabel 6.

Arahan pengembangan variabel fasilitas pendukung

\begin{tabular}{l}
\hline \hline Potensi masalah \\
DTW pantai di DTW pantai di Kabupaten Badung \\
Kabupaten Gianyar \\
belum memiliki pendukung yang lengkap dan mampu \\
fasilitas pendukung \\
atraksi wisata yang pada Pantai Tanjung Benoa telah \\
lengap seperti terdapat fasilitas yang dibutuhkan \\
penyewaan papan wisatawan untuk melakukan wisata tirta \\
selancar, tempat seperti penyediaan sarana, dan \\
bilas dan lain-lain penyediaan tempat bilas \\
Arahan Pengemangan: \\
1. Penyediaan failitas pendukung atraksi wisata seperti tempat \\
penyewaan papan surfing di Pantai Selukat, Saba dan \\
Cucukan serta penyewaan alat pancing pada Pantai \\
Cucukan, Siyut, dan Lebih \\
2. Penyediaan fasilitas berup tempat bilas umum untuk \\
memenuhi kebutuhan wisatawan
\end{tabular}

Sumber: Hasil analisis, 2017

7. Lembaga Pengelolaa Daya tarik Wisata
Tabel 7.

Arahan pengembangan variabel pengelola Potensi masalah Best practice

Sebagian besar objek wisata di Pengelala objek wisata di Kabupaten Gianyar dikelola oleh Kabupaten Badung sebagai desa adat setempat, namun dalam besar sudah memiliki pengelolaan belum memiliki program-program program pengembangan, seperti pengembangan dan pada objek wisata Pantai Siyut, pengelola telah bekerja Goa Alam Sumita, candi Tebing sama dengan pemerintah Sumita, Candi Tebing Tegalingga, dan swasta seperti pada Candi Tebing Pejeng

\section{Arahan Pengemabangan;}

1.Pembentukan kelompok sadar wisata di Desa Sumita, Desa Bedulu, dan Desa Pejeng sebagai kade bagi masyarakat dalam mempromosikan potensi wisata yang dimiliki

2.Pembentukan kesepakatan kerjasama antara pihak pemerintah, masyarakat, dan swasta dalam pengelolaan objek wisata pantai

Sumber: Hasil analisis, 2017

8. Jarak Daya Tarik wisata dengan bandara

Tabel 8.

Arahan Pengembangan variabel jarak dari bandara

Potensi masalah Best practice

Jarak lokasi wisata di Kabupaten Rute transportasi umum Gianyar relatif jauh dari lokasi Sarbagita telah menjangkau Bandara Ngurah Rai. Wisatawan sebagian besar wilayah di cenderung memilih untuk Kabupaten Badung menginap di lokasi yang dekat dengan bandara dan rute kendaraan umum belum menjangkau seluruh wilayah di

Kabupaten Gianyar

Arahan Pengembangan:

Meningkatkan rute perjalanan trnsportasi publik Sarbagita di Kabupaten Gianyar seperti Kecamatan Balahbatuh dan Gianyar Sumber: Hasil analisis, 2017

\section{KESIMPULAN DAN SARAN}

Adapun kesimpulan dari penelitian ini adalah sebagai berikut:

1. Arahan pengembangan pariwisata pada Kabupaten Gianyar difokoskan pada pengembangan atraksi wisata, pengembangan potensi wisata, akomodasi dan restoran, melengkapi fasilitas pendukung atraksi wisata, pembentukan kelompok sadar wisata terutama pada desa wisata, kerja sama antara pemerintah, swasta dan masyarakat dalam mengemangkan potensi wisata yang dimiliki

2. Arahan pengembangan pariwisata pada kabupaten badung difokuskan pada penyediaan fasilitas akomodasi dan restoran pada wilayah utara yaitu Kecamatan Petang, pembentukan kelompok sadar wisata dan kerja sama antara pemerintah, swasta, dan masyarakat dalam pengelolaan daya tarik wisata

\section{DAFTAR PUSTAKA}

[1] A. Y. K. Umilia, Ema. Ketut Dewi Martha Erli, "Pengembangan Air Terjun Coban Pelangi Padang," Universitas Andalas, 2017.

[2] BPS, Provinsi Bali dalam Angka Tahun 2016. Bali: BPS Prov. 
[3] dan T. Dinas Pariwisata Kabupaten Badung, Denpasar, Gianyar, Potensi Pariwisata tahun 2016. Bali, 2016.

[4] Bappenas RI, Seri Analisis Pembangunan Wilayah Provinsi Bali Tahun 2015. Jakarta, 2015.

[5] D. . Prasiasa, Destinasi Pariwisata berbasis Masyarakat. Jakarta: Salemba Humanika, 2010.

[6] A. Maulana, "Tingkat Kepuasan Masyarakat Terhaadap Distribusi Air Bersih di kelurahan tambak Wedi Surabaya," Institut Teknologi Sepuluh Nopember, 2017.

[7] A. A. I. Witari, "Arahan Pengembangan Pariwisata di Bali Selatan; 'Studi Komparasi antara Kabupaten Badung dan Kabupaten Gianyar,"” Institut Teknologi Sepuluh Nopember, 2017. 